\title{
Magnetic Survey at the Roman Military Camp of el Benian in Mauretania Tingitana (Morocco): Results and Implications
}

\author{
Francesco Martorella
}

check for

updates

Citation: Martorella, F. Magnetic Survey at the Roman Military Camp of el Benian in Mauretania Tingitana (Morocco): Results and Implications. Remote Sens. 2021, 13, 28. https:// dx.doi.org/10.3390/rs13010028

Received: 3 November 2020 Accepted: 17 December 2020 Published: 23 December 2020

Publisher's Note: MDPI stays neutral with regard to jurisdictional claims in published maps and institutional affiliations.

Copyright: (c) 2020 by the author. Licensee MDPI, Basel, Switzerland. This article is an open access article distributed under the terms and conditions of the Creative Commons Attribution (CC BY) license (https: / / creativecommons.org/ licenses/by/4.0/).
Department of European and Mediterranean Cultures, University of Basilicata, Via Lanera, 20, 75100 Matera, Italy; francesco.martorella@unibas.it

\begin{abstract}
The topic of military settlements and the role of troops in the northern provinces of North Africa during the age of the Roman Empire has recently gained a strong interest in historical, archaeological, epigraphical, and economic studies. In particular, at Mauretania Tingitana (in the north-east area of modern-day Morocco), the presence of numerous military camps in the Early and Later Roman Empire has now been assessed. In this framework, the present work deals with the geophysical survey, by means of magnetometry, at the site of el Benian, where the largest military camp is located. In particular, the magnetic survey has highlighted the organization of the camp, almost totally unknown previously. The result of the magnetic survey has confirmed intense building activity over the centuries and made it possible to identify and characterize the structures typical of a military field.
\end{abstract}

Keywords: magnetometry; archaeological prospections; roman military camp; roman army; Mauretania Tingitana

\section{Introduction}

The topic of military settlements and the role of troops in the northern provinces of North Africa in the Roman age has always sparked a lot of interest and important research, and historical, archaeological, epigraphical, and economic studies have been carried out and continuously updated, investigated, and debated [1-41].

The present work deals with the area of Mauretania Tingitana (located in the north-east area of modern-day Morocco), where research is ongoing with the aim of gaining new information about provincial military history. In this context, two important contributions are identified due to the work of René Rebuffat [38].

M. Lenoir, a specialist in Roman military architecture, devoted his last work to improving the military camp catalogue of Mauretania Tingitana, by describing the characteristics of ten camps dating back to the middle of the 1st Century AD, at the beginning of the provincial era, and the 5th Century AD [42].

A. Akerraz worked on the archaeological prospecting mission along the Loukkos River. Due to his previous experience in the area, he detected seventeen camps from the early Roman Empire (Tamuda, Aïn Daliya, Tabernae, Frigidae, Banasa, Thamusida, Sala, Khédis, Souiyar/Ad Novas, el Mers, el Kanayez, Fouarat, Souk el Arbaâ, Sidi Saïd, Sidi Moussa Bou Fri, Tocolosida, and Aïn Schkour) and another six from the Later Roman Empire (Tamuda, el Benian, Tabernae, Souiyar, Lamdanna, and el Mers). The camps Tamuda, Tabernae, Souiyar, and el Mers were positioned on top of older camps, while el Benian and Lamdanna were newly founded [1].

The geophysical investigations at the el Kanaiez site did not find confirmation of the presence of a military camp. With the exception of the El Kanayez site, the number of military camps in the Early Roman Empire is sixteen, where the other two camps date back from the Later Roman Empire (see Figure 1). 


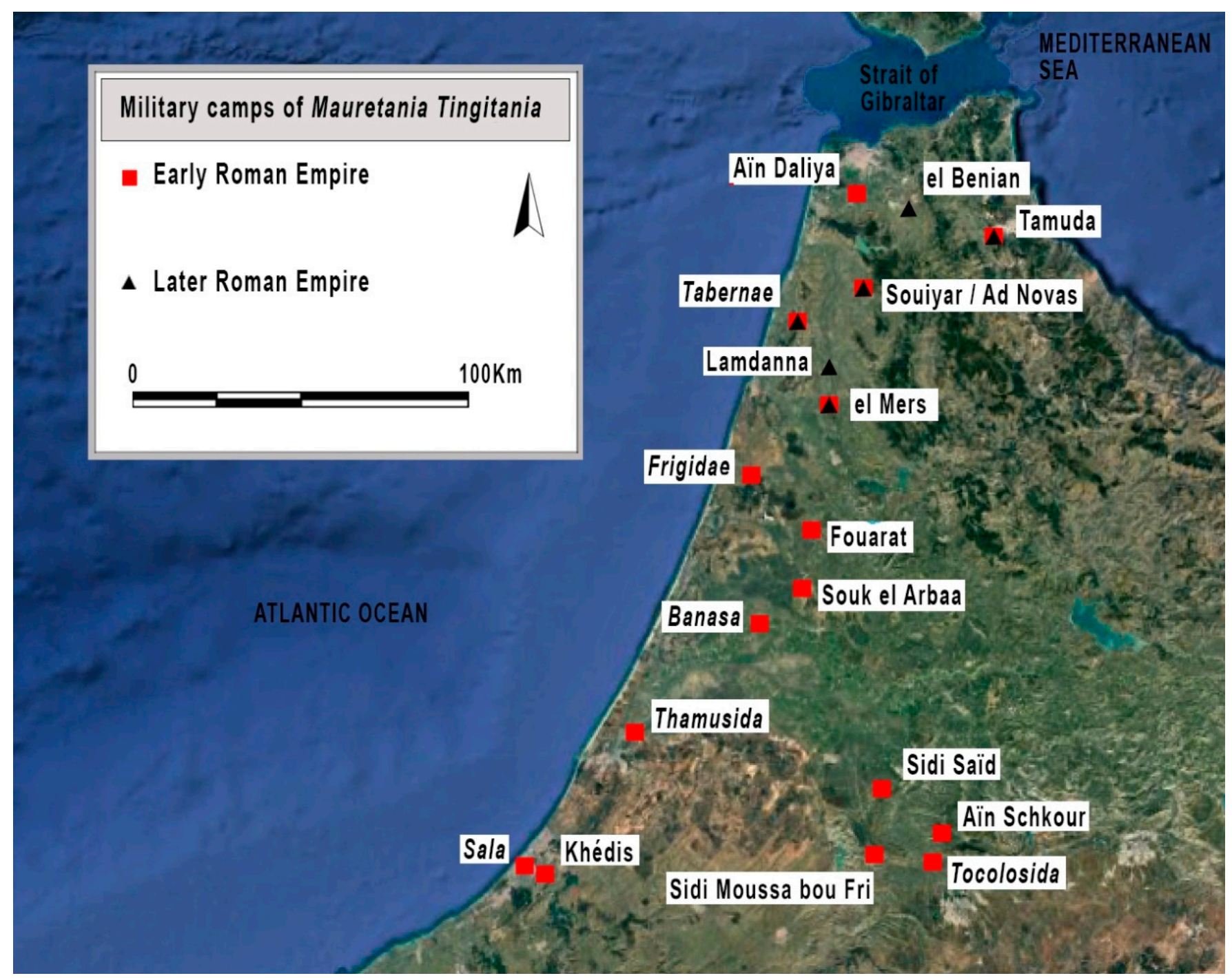

Figure 1. Military camps in Mauretania Tingitana (modified from Google Earth).

The first investigations at the military camp el Benian were performed by Ch. Tissot, who, while working on the seven units of limitanei for the comes Tingitaniae, mentioned the Tribunus Cohortis secundae Hispanorum Duga and identified the camp of el Benian as the castrum of Duga [43]. This information refers to important elements of the whole building with its long perimeter wall, four towers with square corners, and five intermediary turrets. The most credible present hypothesis is the association of the camp with the ancient Pacatiana where the Tribunus Cohortis Pacatianensis Pacatiana stayed while under orders from the comes Tingitaniae [1] (p. 559).

The first excavations were carried out by M. Tarradell in the area of the principia and two specific areas of the south-east city walls (at the center relative to the door and the southern corner). These excavations confirmed the rectangular shape of the camp with rounded corners, perimeter walls $1 \mathrm{~m}$ thick, and quadrangular corner towers (Figures 2 and 3). 


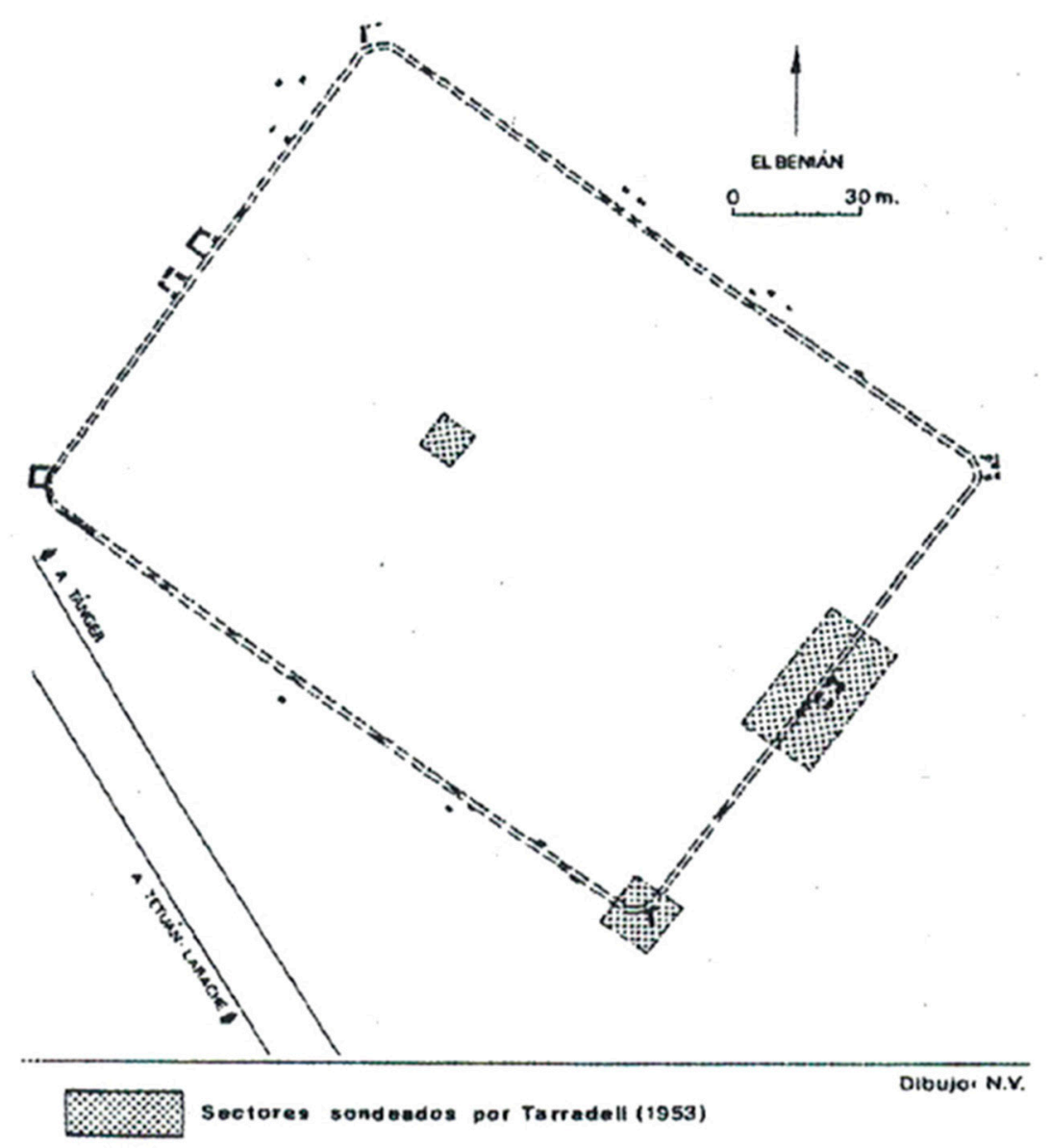

Figure 2. el Benian: plan of the camp showing the three areas of archaeological investigation by M. Tarradell [41] (p. 95, Figure 21).

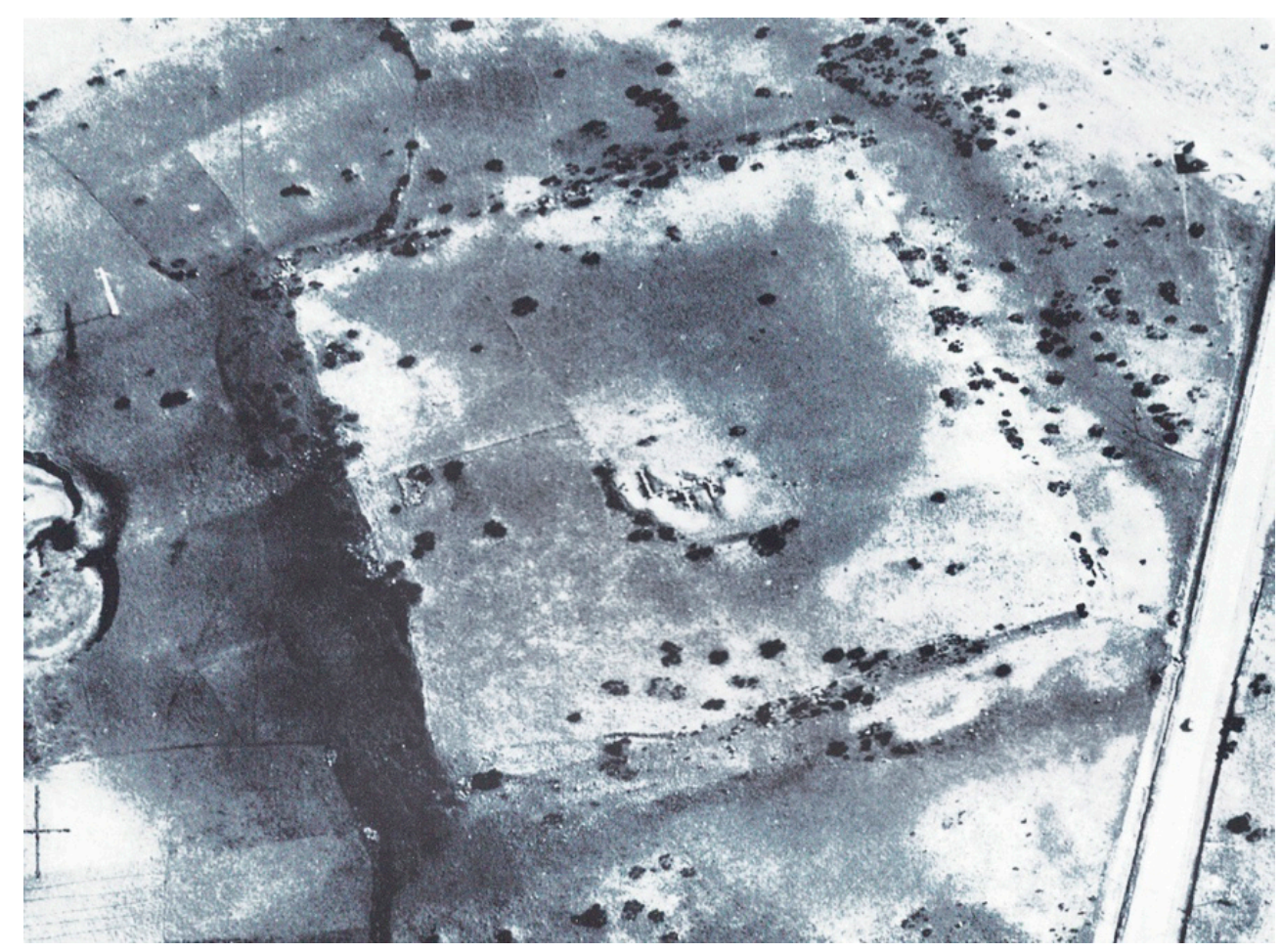

Figure 3. el Benian: aerial photograph with a view from the north-west [44]. 
This paper focuses on the military camp el Benian, which is located half-way between Tangeri and Tetouan, at the foot of Djebel Barhokiyene in a hilly area facing northwest/south-east. The camp is rectangular $(183 \mathrm{~m} \times 140 \mathrm{~m})$ and covers an area with a slight downward slope towards the north-west and faces north-west/south-east [42] (p. 258). The total surface area is estimated to be between 2.46 [45] and 2.56 ha [44] (p. 354); this makes el Benian the largest military camp in Mauretania Tingitana. The north-west city walls have not yet been identified due to the presence of a modern building used for poultry farming with metal boundary fencing. The northern perimeter cannot be determined from the aerial photography and the field surveys were not possible due to the fact that the areas are privately owned. There are two main rivers that represent the main water supplies for the military camp: the es Sania river located to the north, which is an everlasting river, and the Berouâ river close the south-east boundary, which has torrential behavior. This research proved the presence of just one camp, whose origin dates back to the end of the 3 rd century AD and that was operative until the end of the 4th century AD. [46]. The camp had the duty of protecting the area between the Tingi and the camp of Tamuco (Tamuda).

The present work presents some new results provided by the geophysical investigations carried out during the 2015 and 2016 missions at the military camp of el Benian. Since September 2015, non-invasive magnetic surveys have been performed with the aim of understanding the internal layout of the castra and identifying the areas and structures used for the military's provisions. These results were achieved in the framework of the FRAWM "project" (Feeding the Roman Army in the Western Maghreb (FRAWM). Multidisciplinary approach for the study of the army's grain supply in the southern limit of the Roman Empire (province of Mauretania Tingitana), which had the aim to detect the information collected from previous works and to add new archaeological data on the internal layout of the military camps; this is also thanks to new geophysical information. The project started from a close collaboration between the École Française de Rome (EFR) and the Institut National des Sciences de l'Archéologie et du Patrimoine (INSAP). The team also carried out work on the sites of Lalla Djilalya/Tabernae, el Kanayez, el Mers, Lamdanna, and Azib el-Harrak/Frigidae.

\section{Materials and Methods}

Magnetic surveys are based on the identification of changes in the Earth's magnetic field caused by changes in the geology of the soil or by the presence of structures and objects in the subsoil that can give rise to magnetic anomalies. In the field of archaeological research, magnetic prospecting is one of the most widespread investigation techniques for large investigation areas. The main advantages are: (1) the anthropic traces usually show a strong contrast of magnetization with respect to their surroundings; (2) the fastness of the measurement and light weight of the sensors allow mapping of large surfaces with a high density of data [47-52].

At the archaeological site of el Benian, field activities were carried out by means of a fluxgate FM256 (Geoscan) gradiometer which acquired the gradient of the magnetic field through two sensors placed $0.50 \mathrm{~m}$ from each other along a non-magnetic support.

Regarding calibration and compensation, the instrument required precise calibration before each session of measurements to correct errors of sensitivity, offset, and angle. In this research, the calibration consisted of the rotation of the device in all directions around a fixed point where the magnetic field can be considered steady.

The topographic survey was carried out with a differential global positioning system (DGPS) and a Leica Total Station, acquiring static precision points of visible structures (walls of the principia area still in situ) and surrounding modern buildings. With the use of a DGPS, it was possible to position the points useful for geophysical prospecting on a detailed map and to discriminate areas with low archaeological potential and with poor visibility. The geophysical reliefs were anchored to a system of 73 square grids of $20 \mathrm{~m} \times 20 \mathrm{~m}$, with an orientation of $30^{\circ}$ with respect to the alignment of the visible perimeter structures. 
At el Benian military camp, the limits of the investigations, agreed with the Moroccan institutions, were affected by the presence of private ownership coinciding with the boundary of the camp. The investigated area was 29,200 square meters (2.92 hectares), which was divided by $20 \mathrm{~m} \times 20 \mathrm{~m}$ sub-areas (Figure 4 ). Each of the sub-areas was investigated by magnetic instrument along parallel profiles with $1 \mathrm{~m}$ spacing and the measurement walk step along each profile was $0.5 \mathrm{~m}$ (Figure 5). Therefore, for each sub-area, 810 measurements were collected with a total number of measurements of 59,200. The recorded values were processed using the Geoplot 3.0 program (Geoscan Research).

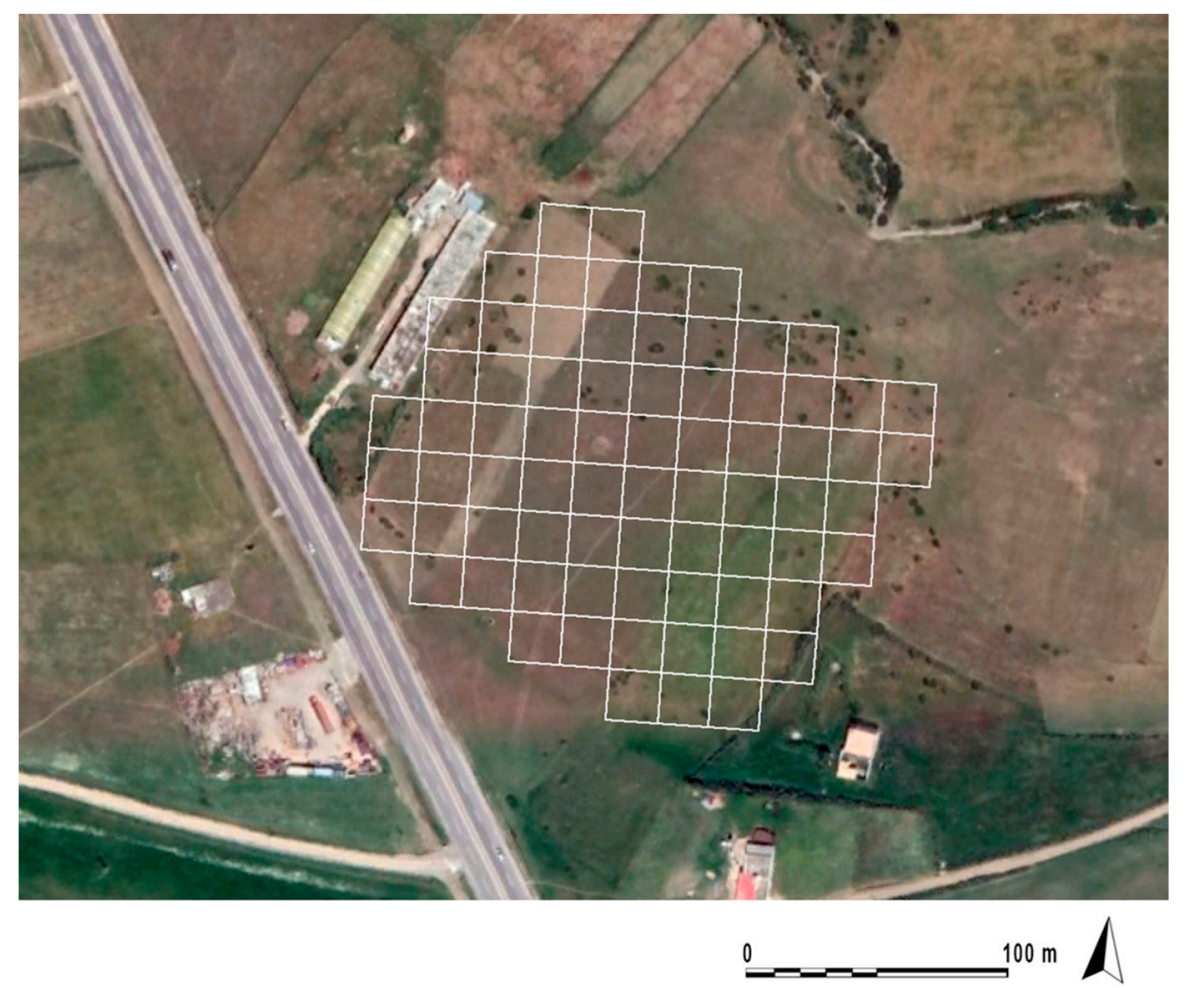

Figure 4. el Benian: military camp area with a square grid quadrate $(20 \mathrm{~m} \times 20 \mathrm{~m})$. To the left, the National Highway Two connecting Tangeri with Tetouan.

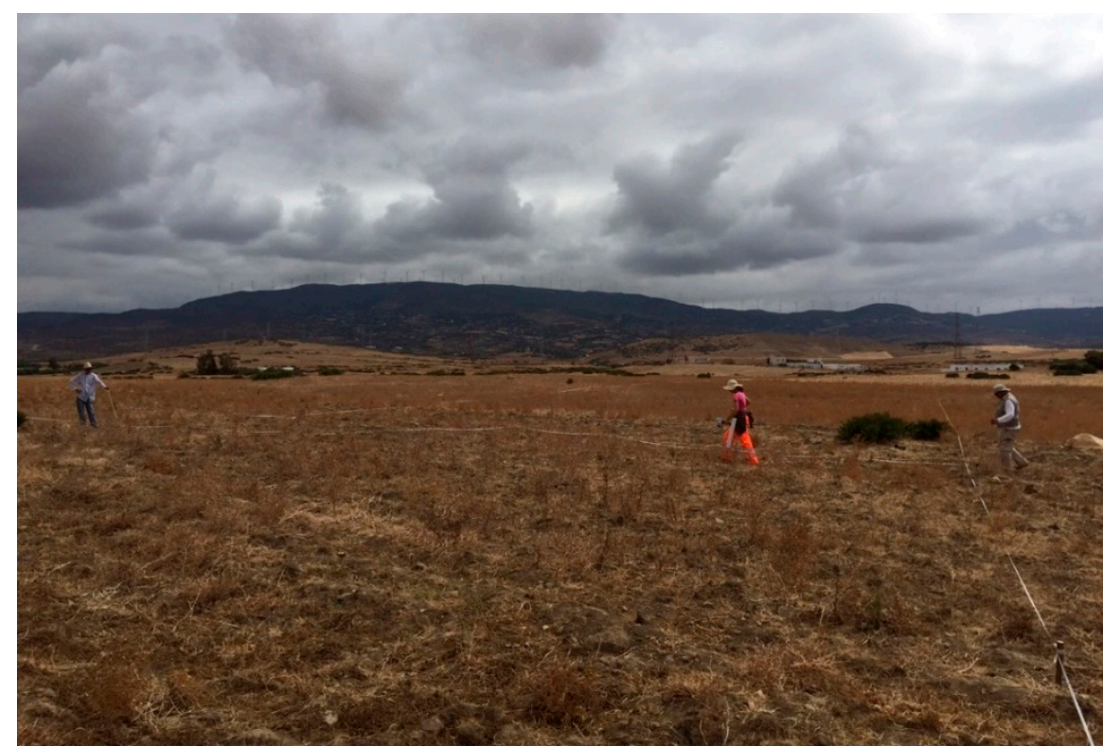

Figure 5. el Benian: geophysical prospecting in the southern corner. 
The data processing stage consisted of several steps. At the first step, each grid of data files was transformed into a composite file by concatenating the data from individual survey grids into a single composite matrix. The second step consisted of the despiking of extreme values. This process (Despike) consists of scanning the data by using a uniform weighted window and looking for datapoints that exceed the mean of the window by a specified threshold amount. The following step was the destriping that was applied along each traverse; in this operation, the mean of each traverse is determined and then subtracted from each datapoint along the traverse; this step is used to remove the striping effect caused by directional effects, operator clothes, and instrument setup. An edge matching of data values in adjacent grids through balancing of brightness and contrast (i.e., means and standard deviations) was performed.

After this, the data were interpolated by increasing the number of data points in the traverse direction and by reducing the number of data points in the sampling direction in order to provide a smoother visualization of the data set. Next, a low pass filter was then applied over the entire dataset to remove any high frequency, small scale spatial detail. This transformation is necessary to improve the visibility of larger, weak archaeological features.

After all the data processing steps, the final magnetic map of the investigated area was achieved (Figure 6), where several anomalies are well detected.

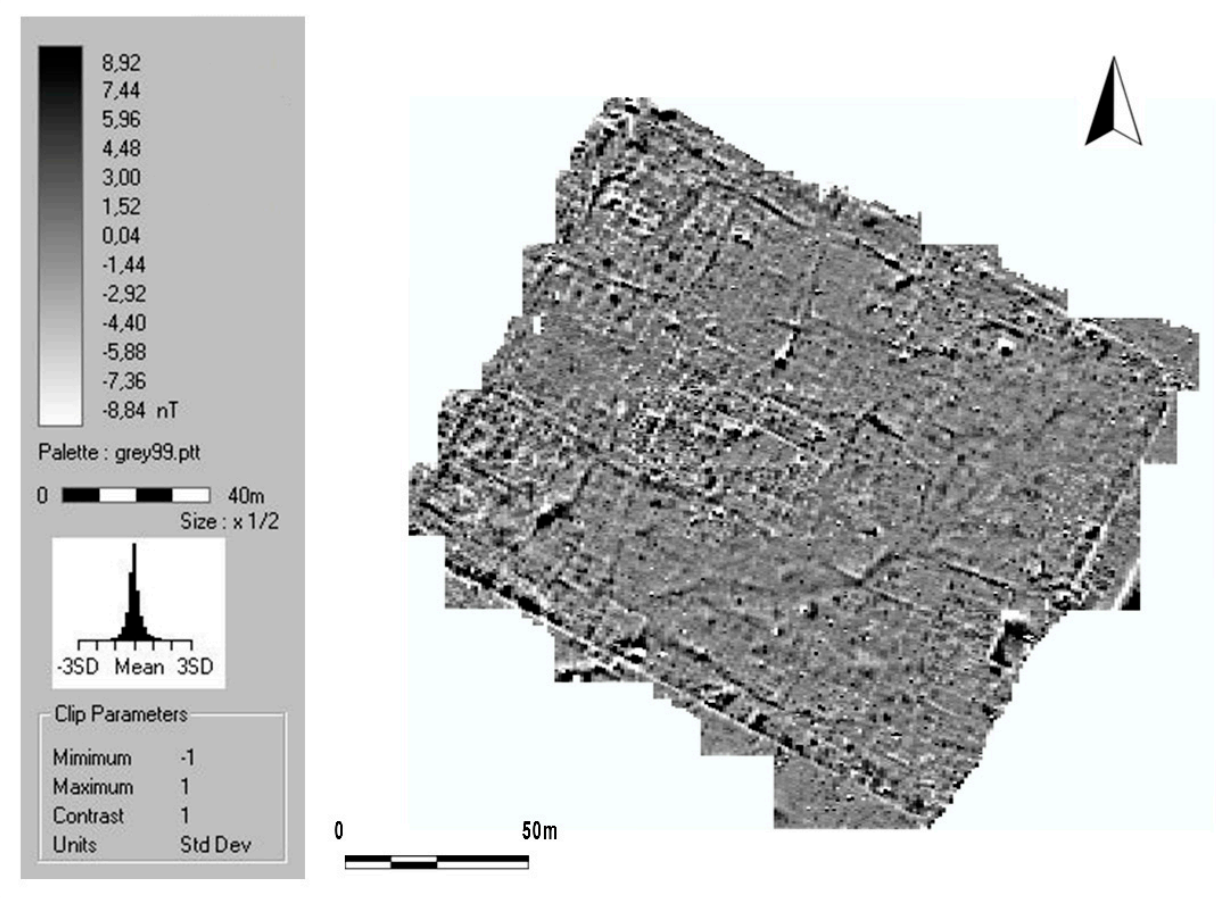

Figure 6. Gradiometric map obtained in the military camp el Benian. To the left, a gray scale blade sensitive to changes in the magnetic gradient with a range from +9.12 to $-8.84 \mathrm{nT}$ (nano-Tesla). (F. Martorella and L. Cerri).

\section{Results and Discussion}

The magnetic gradient map in Figure 6 highlights several linear anomalies corresponding to numerous buried wall structures.

Figure 7 shows the gradiometric map with the interpretation of the main anomalies, which could be associated to the thick structures of the buildings disposed in the military camp during the different historical time phases. 


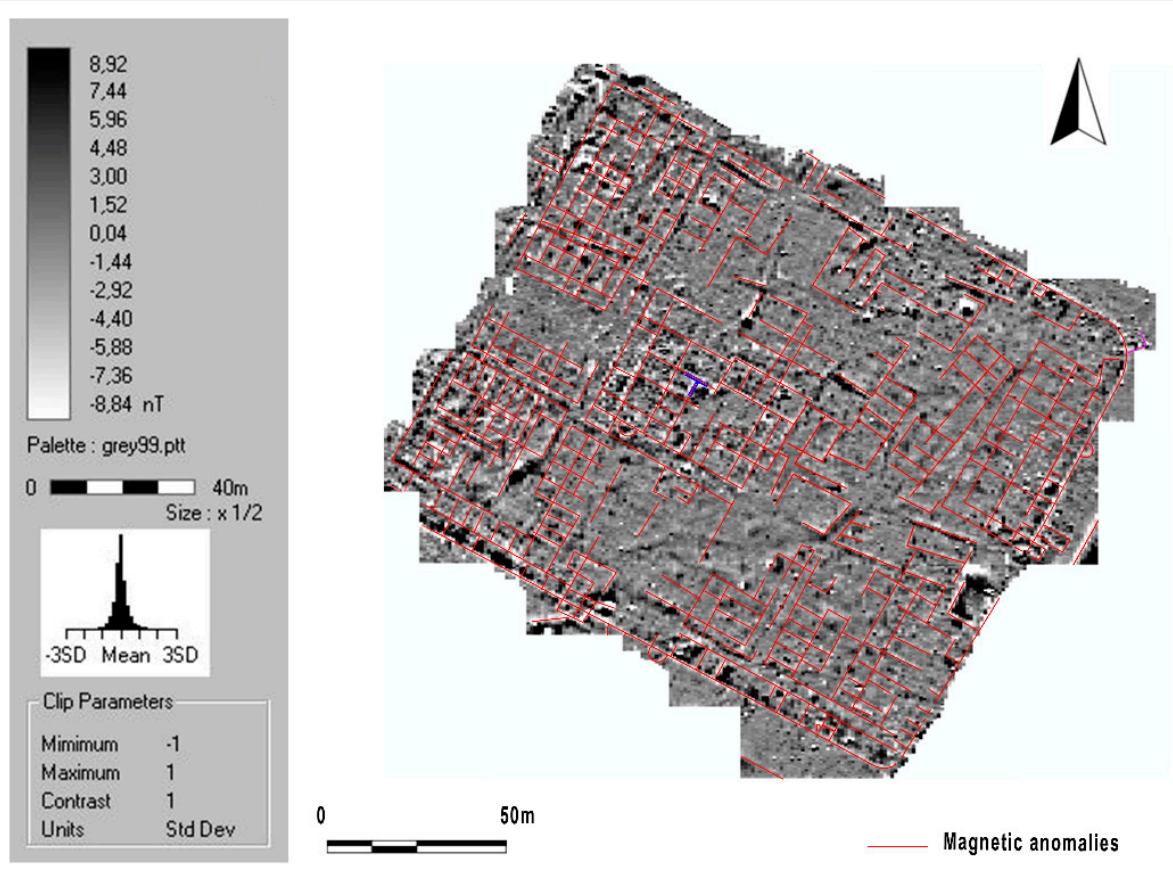

Figure 7. el Benian military camp. Magnetic anomalies with map of the vertical magnetic gradient.

Based on the result shown in Figure 7, the extent and boundaries of the military camp can be identified, confirming the estimated width of $140 \mathrm{~m}$. The length was not measurable due to the presence of modern structures in the north-west part. The interpretated linear network helped us to reconstruct the military framework plan, also taking into account the suggestions of previous studies. They highlight the presence of square blocks of stone in the area as well as Roman pottery and fragments of cocciopesto. Some portions of masonry were still visible inside the M. Tarradell surveys in the place of the principia (see Figure 2) and in the excavation surveys carried out by the INSAP-Universite Abdelmalek Essaâdi missions in Tetouan in the middle north-west area, where thermal structures aligned with the west gate were well delineated.

The structures belong to late chronological phases that cannot be better identified, but they are certainly advanced compared to the first settlement phases. On the north and south sides, large square blocks are visible which can be traced back to sections of the city walls whose alignments are confirmed by the evident magnetic anomalies.

The merging studies between the geophysical results and the historical analysis defined the main alignment on the magnetic map (Figure 7).

The magnetic alignments also allowed for a better understanding of the internal organization of the military camp [42] (pp. 11-41).

The internal spaces are divided into three sections (praetentura; principia and latera praetorii; and retentura) by two transverse roads (via principalis and via quintana). The via quintana runs between the sides of the principia and the retentura. The principal street (via principalis) connecting the side gates crosses the axis of the fort and links the gate praetoria and the principia. The retentura and praetentura are further divided into two by longitudinal streets (via pretoria and via decumana). In fact, in the central part of the retentura the scarce presence of magnetic anomalies suggests the presence of another road axis (via decumana) in the direction of the north-west gate (porta decumana) (Figure 8). 

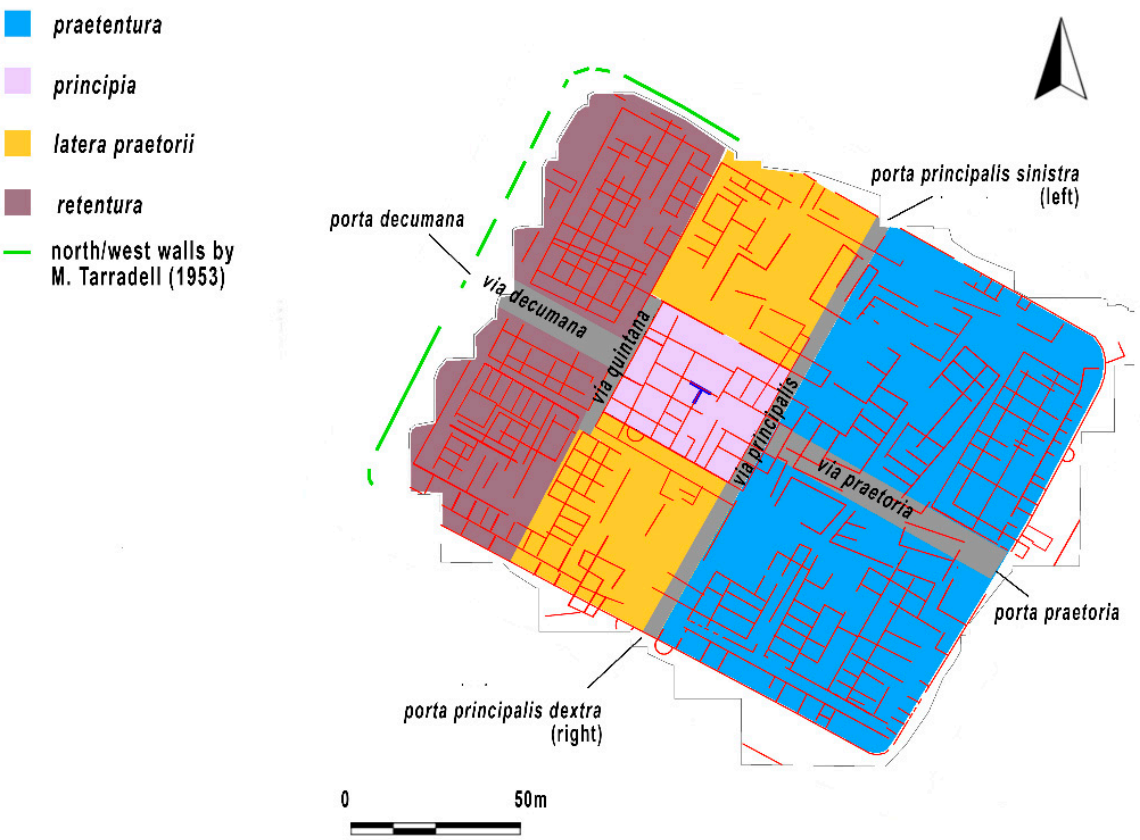

Figure 8. Internal organization (areas) and indication of all magnetic anomalies.

The hypothesized organization of the internal areas made it possible to discriminate anomalies with different orientation and anomalies on movement spaces originally free from wall structures (in particular, road axes). More accurate magnetic data processing clearly showed at least two different orientations, which mainly affect the eastern area of the military camp. If road axes are also considered, several structures probably did not belong to the primary phase of the camp (Figure 9).

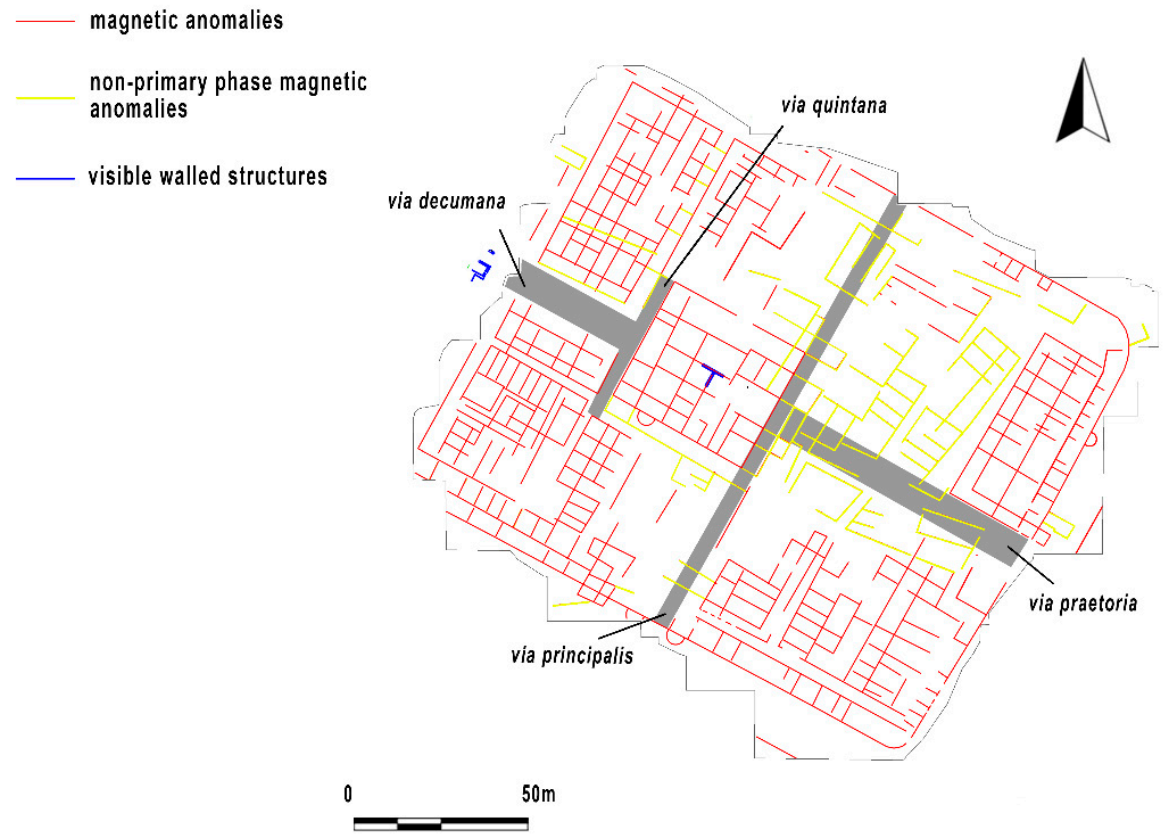

Figure 9. el Benian military camp. Interpretated magnetic map and main road.

Anomalies, probably attributable to the presence of a moat, were highlighted outside the wall in the middle part of the short side with a south-west/north-east orientation, at about 20 m east from the east gate (Figure 10, number 4) and at the south, outside the 
walls facing south-east/north-west, about $60 \mathrm{~m}$ west from the south corner of the wall (Figure 10, number 5).

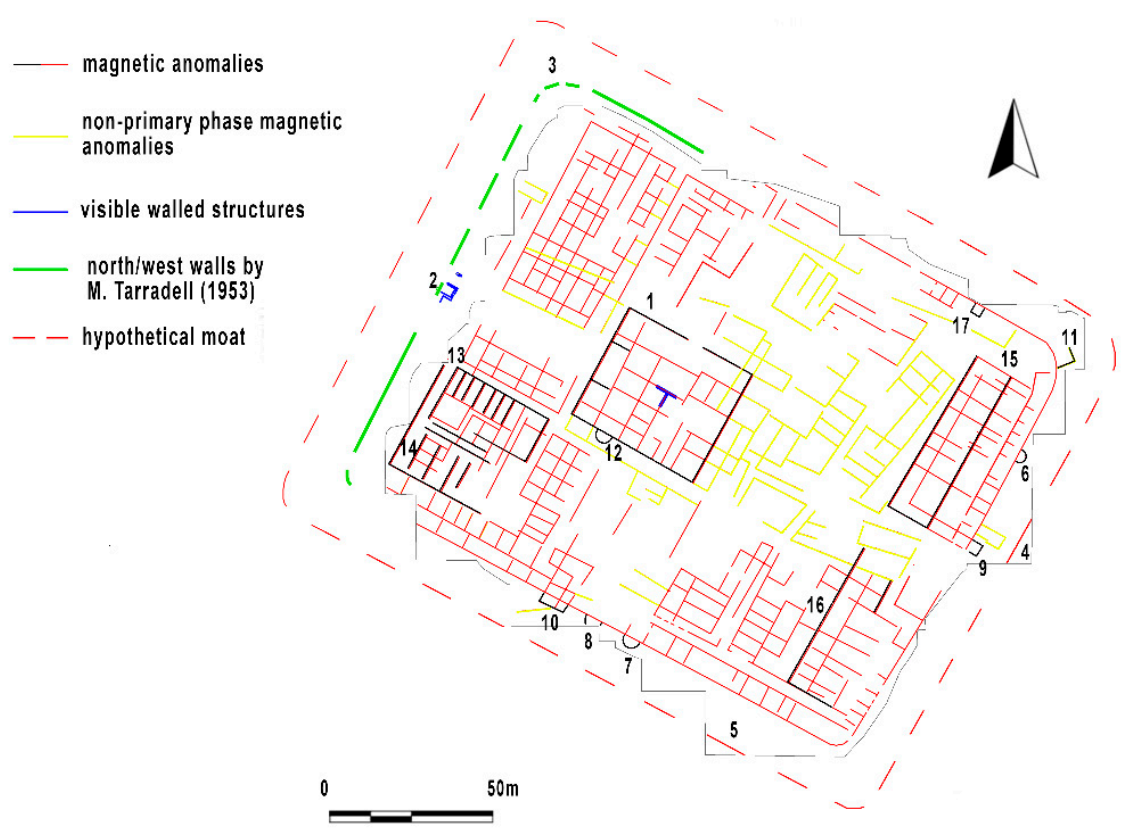

Figure 10. Interpretation of the magnetic anomalies: 1. principia; 2 . thermal structures; 3 . perimeter of the walls; 4 . moat south-west/north-east; 5 . moat south-east/north-west; 6 . east semicircular structure; 7-8. southern semicircular structures; 9 . east tower; 10 . Rectangular structure; 11 . tower; 12. apsidal structure; 13-14. rectangular buildings (warehouses); 15-16. soldiers lodgings; 17. internal quadrangular tower.

Anomalies attributable to semi-circular structures leaning against the city walls were highlighted in the median position outside the walls with a south-west/north-east orientation (Figure 10, number 6) and at the south on the sides featuring the right side gate (Figure 10, number 7 and number 8). The hypothesis that anomaly number 8 might be a circular tower seems to find evidence on the ground, where slight levelling is visible.

The orientation of the two intermediate square towers, visible at the north side of the wall with a south-east/north-west in M. Tarradell's plan (see Figure 2) is not reflected in the magnetometric data because they are located outside of the investigated area. On the other hand, the anomalies attributable to a section of the square tower at the short east side are visible (Figure 10, number 9); these are the tower to the east of the east gate and a section of the wall of a structure visible in the middle part of the long south walls with south-east/north-west orientation (Figure 10, number 10). These anomalies are reflected in M. Tarradell's plan (see Figure 2).

Based on the information from $\mathrm{Ch}$. Tissot and the data from $\mathrm{M}$. Tarradell, it is supposed that the whole city wall was armed with quadrangular towers in the curved sides. It was not possible to verify the presence of anomalies concerning the angular towers to the north and the west. The square tower at the southern corner was already almost totally destroyed at the time of M. Tarradell's excavations. Only one anomaly (a tower) attributable to the rounded corner at the east was identified by the non-invasive investigation (Figure 10, number 11).

Given the scarce surface evidence, Lenoir [42] (p. 258) confirmed the non-visibility of the internal routes. Non-invasive investigations have therefore proved to be particularly useful as regards the definition of the road axes and the adjacent areas; the magnetometric prospections highlighted free spaces between the principia and the side gates, with a greater thickening of structures in the area of the left side gate to the north. 
As regards the occupation of the areas inside the camp, construction activities are concentrated mainly in the angular areas, particularly dense at the south and north corners and in the central part of the principia, where an apsidal environment can be also distinguished (Figure 10, number 12) and numerous anomalies characterized by very high magnetic values attributable very likely to the presence of cocciopesto floors still in place.

At the inner west corner, strong anomalies were highlighted, referring to robust wall structures, probably very well consolidated, attributable to two large buildings: one at the north (36 $\mathrm{m} \times 21 \mathrm{~m}$ approximately; Figure 10, number 13), flanked to the south from a second building of equal length (the anomaly that seems to be interrupted in the south corner must have had to close the south corner), but of a smaller area (36 m $\times 15 \mathrm{~m}$; Figure 10, number 14). Internal anomalies referable to partitions parallel to the short sides with south-west/north-east orientation are visible. This likely suggests, in this position, the existence of the camp warehouses in retentura. In this case, these are double and side-by-side warehouses of which no anomalies relating to external buttresses were found.

At the south-east part, it is possible to determine the soldiers lodgings consisting of elongated, narrow buildings, subdivided inside into various rooms subsequently occupied and flanked by other structures (Figure 10, number 15 and number 16).

\section{Conclusions}

At the end of the 3rd century AD, with the withdrawal of the military army from the south of the province, the defense system was reinforced in the north of the Tingitana with the construction of new military camps (el Mers, Lamdanna, el Benian, and Souiyar/ Ad Novas). Considering the dimensions of the camp, el Benian had a considerable role as a logistic base in the Later Empire, comparable to that of Thamusida camp (Early Empire) in the south of the province. The camp of Thamusida was abandoned at the end of the 3rd century AD. The military camp of el Benian was supposed to guarantee the safety of a large area through a controlled system of watchtowers and other defensive systems.

According to Aomar Akerraz and el Benian (Pacatiana?), the el Beniana camp was under the control of the Tribunus cohortis Pacat ianensis [1]. The moat of the field would not have been very dissimilar from the one found around the military camp of Lamdanna, located at east of the small center of Tlata Raïssana on the confluence of the rivers Harten and Mguerouen; in this area, the works of the Office National de l'Eau Potable (ONEP) have discovered part of the moat limits in one incidental section (approx. $6 \mathrm{~m}$ ). At el Benian, the moat has been specifically documented at the south-west and north-west of the area investigated by the magnetic prospections conducted in the site (Figure 11).

The archaeological research carried out in the castellum of Tamuda provided to be particularly useful in understanding some elements present in the camp of el Benian:

1. intense urban planning activities that were performed at open spaces and free areas initially filled by main roads (Figure 12);

2. confirmation of the presence of internal quadrangular towers and external semicircular towers leaning against the walls of the military camp.

At Tamuda, the archaeo-architectural analysis of the doors and towers (quadrangular and circular) and the results of the stratigraphic excavations have highlighted numerous chronological phases [53]. The construction of the camp with linear walls, made with the opus incertum technique, dates back to 40 A.D., at the same time as the foundation of the province. Starting from the beginning of the 2nd century A.D., there are numerous construction phases characterized by the construction of internal quadrangular towers (2nd century A.D.) and external semicircular towers (late 2nd century A.D. and first half of the 3rd century A.D.). This type of semicircular tower will have had its maximum expansion in the period of the Severan Dynasty (193-235 A.D.). Differently, the construction of the external north-east and south-east corner towers is dated to the beginning of the 4th century A.D., [53,54] (Figure 12b). The abandonment of the military camp dates back to the beginning of the 5th century. A.D., coinciding with the withdrawal of the last border militia. 


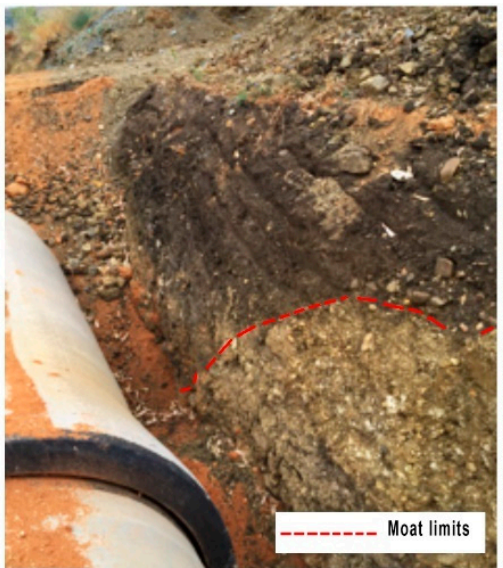

a

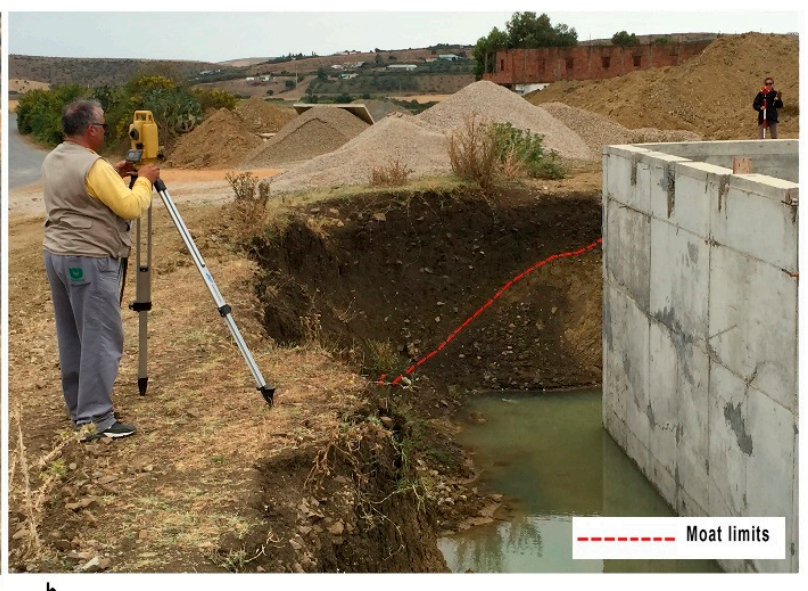

b

Figure 11. Lamdanna. Moat of the military camp. (a) North-west/south-east section of the moat with Scheme 18. or 20 units, had to be perfectly integrated into the system of the annona militaris and the army had to be guaranteed with a fairly effective system of supply. Geophysical investigations conducted in the field of el Benian have highlighted the existence of warehouses having typology (a system of parallel partitions) similar to those found in the field of Tabernae $(36 \times 15 \mathrm{~m})$ and Lamdanna $(30 \times 12 \mathrm{~m} \mathrm{ca})$. The geophysical data defines, therefore, an intense construction activity within the camp, equal or apparently more fervent than that attested in the castellum of Tamuda, located not far from the camp of el Benian (see Figure 1).

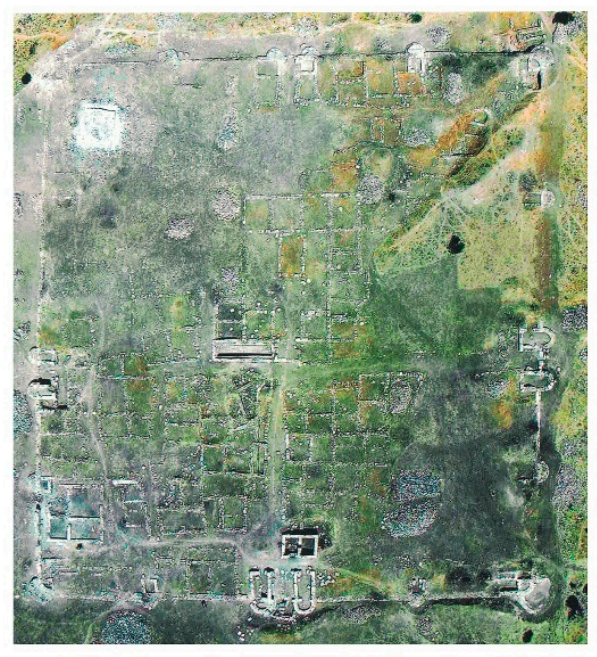

a

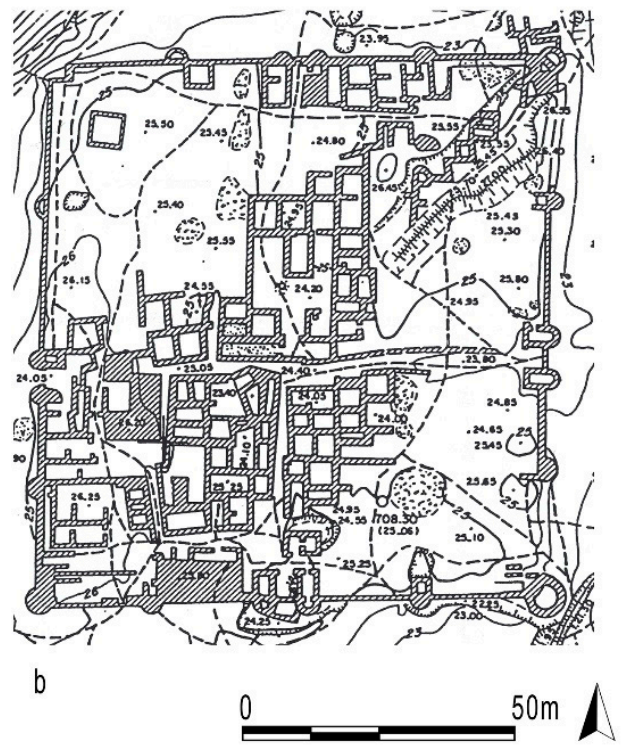

$50 \mathrm{~m}$

Figure 12. Castellum of Tamuda. (a) Aerial view [54]; (b) Photogrammetric restitution [42] (pp. 253-257).

The results of similar and integrated magnetic surveys conducted inside military camps in the ancient provinces of the Empire proved to be very useful in evaluating the response of the magnetic method in understanding the internal organization of the camps [55-58]. The magnetic data acquired at the military camp of el Benian find closer and useful comparisons with the results of the magnetic investigations conducted in the Thamusida camp, in the same province of Mauretania Tingitana (see Figure 1) [59]. Thanks to magnetic surveys, the subsequent stratigraphic excavations, conducted by the University of Siena and the Institut National des Sciences de l'Archéologie et du Patrimoine within the military camp of the ancient city, confirmed the presence of soldiers' lodgings in the praetentura area [60-63] and the presence of warehouses in the retentura area. 
Inside the military camp of el Benian, magnetic surveys highlighted the presence of buildings belonging to the primary phase (principia, soldiers' lodgings, and warehouses). Obviously, the military camp was rebuilt and reused in later chronological phases (see the numerous anomalies in the north-west area). These changed the internal organization, occupying spaces (see the area north of the praetentura) and road axes (see the anomalies on the via principalis and via pretoria).

In the light of the geophysical and planimetric data, thanks to an easier reading of the internal organization of the field, stratigraphic investigations will be able to provide additional data, more precise information and new chronologies (a camp of the early Empire?).

Funding: This research was funded by FP7-PEOPLE, grant agreement ID: 328102.

Acknowledgments: I am particularly grateful to Catherine Virlouvet, past director of the École Française de Rome (EFR) and the collaborators involved at various levels for having embraced the FRAWM "Feeding the Roman Army in the Western Maghreb (FRAWM). Multidisciplinary approach for the study of the army's grain supply in the southern limit of the Roman Empire (province of Mauretania Tingitana)" project like a Host Institution. Catherine Virlouvet coordinated all the application phases and the project work between 2013 and 2017. The project would not have had the same outcome and positive results without the crucial input of Aomar Akerraz, past director of the Institut National des Sciences de l'Archéologie et du Patrimoine (INSAP), Scientist in charge in the Outgoing phase. The field activities were coordinated by Francesco Martorella with the technical support of Laura Cerri (archeologist specialized in geophysics) who I thank for the whole-hearted commitment in the collection of the magnetometric data, Piero Lusuardi (engineer) and Brahim Mlilou (Curator of the archaeological site Lixus-Larache), indispensable for the organization of the field work, Enzo Rizzo for his suggestions on the organization and writing of the paper.

Conflicts of Interest: The author declares no conflict of interest.

\section{References}

1. Akerraz, A. Les fortifications de la Maurétanie tingitane. Comptes Rendus l'Académie Inscriptions Belles Lett. 2010, 154, 539-561. [CrossRef]

2. Baradez, J. Fossatum Africae, Recherches aeriennes sur l'organisation des confins sahariens à l'epoque romaine. Am. J. Archaeol. 1951, 55, 215. [CrossRef]

3. Benseddik, N. Les Troupes Auxiliaires en Mauritanie Cesarienne sous le Haut Empire; Publication autorisée par le jury: Alger, Italy, 1982.

4. Cagnat, R. L'armée Romaine d'Afrique et L'occupation Militaire de l'Afrique sous les Empereurs, Paris; Erdkamp, P., Ed.; A Companion to the Roman Army: Oxford, UK, 2007.

5. Euzennat, M. La frontière d'Afrique 1976-1983, Studien zu den Militärgrenzen Roms III, 13. Int. Limeskongress 1986, 13, 573-583.

6. Fentress, E.W.B. Numidia and the Roman Army. In Social, Military and Economic Aspects of the Frontier Zone; BAR International Series 53; BAR: Oxford, UK, 1979.

7. Laporte, J.-P. Rapidum. Le Camp de la Cohorte des Sardes en Maurétanie Césarienne; Sassari, Italy, 1989.

8. Le Bohec, Y. Les unités auxiliaires de l'Armée romaine en Afrique proconsulaire et Numidie sous le Haut Empire. 1989. Available online: https: / / www.persee.fr/doc/etaf_0768-2352_1989_mon_3_1 (accessed on 15 July 2020).

9. Le Bohec, Y. La troisième légion Auguste; Centre national de la recherche scientifique (CNRS): Paris, France, 1989.

10. Le Bohec, Y. Un Nouveau type D'unité Connu par L'epigraphie Africaine; Hanson, W.S., Keppie, L.J.F., Eds.; Roman Frontier Studie: Oxford, UK, 1979; pp. 931-942.

11. Le Bohec, Y. L'ala Flavia ou ala I Flavia Numidica. Lib. Ant 1978, 15, 139-151.

12. Le Bohec, Y. L'Armée Romaine en Afrique et en Gaule; Franz Steiner Verlag: Stuttgart, Germany, 2007.

13. Le Bohec, Y. La recherche récente sur l'armée romaine d'Afrique (1977-1989). AntAfr 1991, 27, 21-32. [CrossRef]

14. Le Bohec, Y. La stratégie de Rome en Afrique de 238 à 284, Histoire et Archeologie du l'Afrique du Nord. 110e Congrés national des Sociétes Savantes (Montpellier 1985); Comité des travaux historiques et scientifiques (C.T.H.S.): Paris, France, 1987; pp. 377-381.

15. Le Bohec, Y. Le pseudo "camp des auxiliaires" à Lambèse. Armée Romaine Prov. 1977, 2, 71-79.

16. Rebuffat, R. Au-delà des camps romains d'Afrique mineure: Renseignement, contrôle, penetration. ANRW 1982, II.10.2, 474-513.

17. Rebuffat, R. Bu Njem 1972. Libya Antiqua 1977, 13, 37-77.

18. Rebuffat, R. La frontière de la Tingitane. In Hommages à Pierre Salama; Publications de la Sorbonne: Paris, France, 1999 ; pp. 265-286.

19. Erdkamp, P. The Corn Supply of the Roman Armies during the Principate (27 BC-235 AD). In The Roman Army and the Economy; Erdkamp, P., Ed.; Gieben: Amsterdam, The Netherlands, 2002; pp. 47-69.

20. Erdkamp, P. The Grain Market. In the Roman Empire; Cambridge University Press: Cambridge, UK, 2009.

21. Le Bohec, Y. L'armée e l'organisation de l'espace urbain dans l'Afrique Romaine d'haut empire. L'Africa Romana 1992, 11, 313-320. 
22. Martorella, F. La conservazione delle derrate Nuove metodologie di indagine applicate allo studio di due magazzini di età imperiale (I-III d.C.) nelle città di Thamusida e Banasa (Mauretania Tingitana, marocco). HEROM J. Hell. Rom. Mater. Cult. 2020, 9, 233-251.

23. Morizot, P. Impact de l'armée romaine sur l'économie de l'Afrique. In The Roman Army and the Economy; Erdkamp, P., Ed.; Gieben: Amsterdam, The Netherlands, 2002; pp. 345-374.

24. Garnsey, P.; Saller, R. The Roman Empire: Economy, Society and Culture; University of California Press: Richmond, VA, USA, 1987.

25. Papi, E.; Martorella, F.; della Tingitana, I.G.; Papi, E. (Eds.) Supplying Rome and the Empire. J. Rom. Archaeol. Suppl Portsm. 2007, $69,85-96$.

26. Rickman, G. Roman Granaries and Store Buildings, Cambridge; Cambridge University Press: London, UK, 1971.

27. Salido Dominguez, J. Horrea Militaria. In El Aprovisionamiento de Grano al Ejército en el Occidente del Imperio Romano; Ediciones Polifemo: Madrid, Spain, 2011.

28. Akerraz, A.; Lenoir, E.; Rebuffat, R. Plaine et montagne en Tingitane méridionale, Histoire et archeologie du Nord., Actes du IIIe Colloque Internationale (Montpellier, 1-5 avril 1985); Comité des travaux historiques et scientifiques (C.T.H.S.): Paris, France, 1986; pp. 219-255.

29. Akerraz, A.; Lenoir, E. Volubilis et son territoire au Ier siècle de notre ère, dans L'Afrique dans l'Occident romain, Actes du Colloque (Rome, 3-5 décembre 1987); École Française de Rome: Rome, Italy, 1990; pp. 213-229.

30. Carcopino, J. Le Maroc Antique; Gallimard: Paris, France, 1943.

31. Colin, J. L'occupation romaine du Maroc; Cours Préparatoire au Service des Affaires Indigenes (Direction Génerale des Affaires Indigènes): Rabat, Morocco, 1925.

32. Di Vita-Evrard, G. L'édit de Banasa: Un document exceptionelle? In Proceedings of the L'Africa romana 5, Atti del V Convegno di Studio, Sassari, Italy, 11-13 December 1987; Mastino, A., Ed.; Volume 5, pp. 287-304.

33. Euzennat, M. Le limes de Tingitane: La Frontière Méridonale, Études D'antiquités Africaines; Centre national de la recherche scientifique (CNRS): Paris, France, 1989.

34. Lasala Navarro, I. Caelestia animalia Mauretaniae: Una breve reflexion a proposito del edicto de Banasa. Ktema 2008, 33, 413-420.

35. Martorella, F. An urban warehouse for foodstuffs in the Iulia Valentia Banasa colony (Mauretania Tingitana, Morocco). Antiquités Afr. 2020, 56, 61-77.

36. Rebuffat, R. L'implantation militaire romaine en Maurétanie Tingitane. In Proceedings of the L'Africa romana 4, Atti del IV Convegno di Studio, Sassari, Italy, 12-14 December 1986; Volume 4, pp. 31-78.

37. Rebuffat, R.; et Limane, H. Carte archeologique du Maroc antique. 1. In Le bassin du Sebou; Imprimerie El Maarif Al Jadida: Rabat, Morocco, 2011.

38. Rebuffat, R. L'armée romaine de Maurétanie tingitane. Mélanges l'École Française Rome Antiquité 1998, 110-1, 193-242. [CrossRef]

39. Rebuffat, R. Le discours oral du prince, Mélanges de l'École française de Rome. Antiquité 2002, 114-2, 1011-1024.

40. Villaverde Vega, N. El ejército romano en la provincia de Mauretania Tingitana entre Diocleciano y Valentiniano I. In Proceedings of the L'armée romaine de Diocletien à Valentinien Ier, Lyon, Italy, 12-14 September 2002; Le Bohec, Y., et Wolff, C., Eds.; pp. $299-305$.

41. Villaverde Vega, N. Tingitana en la Antigüedad Tardía (siglos III-VII): Autoctonía y Romanidad en el Extremo Occidente Mediterráneo; R.A.H. Biblioteca Archaeologica Hispana: Madrid, Spain, 2001; Volume 11.

42. Lenoir, M. Le Camp Romain. Proche-Orient et Afrique du Nord; Bibliothèque des École françaises d'Athènes et de Rome; École française de Rome: Rome, Italy, 2011.

43. Tissot, C. Recherches sur la géographie comparée de la Maurétanie tingitane. In Mémoires Présentés par Divers Savants à l'Académie des Inscriptions et Belles-Lettres; 1e sér., t.9; Imprimerie Nationale: Paris, France, 1878; pp. 307-308.

44. Ponsich, M. Recherches archéologiques à Tanger et dans sa région; Éditions du Centre national de la recherche scientifique: Greensboro, NC, USA, 1970.

45. Villaverde Vega, N. Recherches sur les camps romains du Maroc, campagne 1991. La stratégie militaire du Bas-Empire en Maurétanie tingitane. In Actes du VIe Colloque International sur l'histoire et l'archéologie de l'Afrique du Nord. Antique et Médiévale, Pau, october 1993; CTHS: Paris, France, 1995; pp. 343-364.

46. Tarradell, M. El Benian, castellum romano entre Tetouan y Tanger, Tamuda 1; Tetuán, Spain, 1953; pp. 302-309.

47. Fedi, M.; Cella, F.; Florio, G.; La Manna, M.; Paoletti, V. Geomagnetometry for Archaeology. In Sensing the Past; Masini, N., Soldovieri, F., Eds.; Springer: Berlin/Heidelberg, Germany, 2017; pp. 203-230.

48. Aitken, M.J. Magnetic prospecting. I. The Water Newton Survey; Archaeometry 1; Oxford University: Oxford, UK, 1958 ; pp. 24-29.

49. Florio, G.; Cella, S.F.; Castaldo, L.; Pierobon-Benoit, R.; Palermo, R. Multiscale techniques for 3D imaging of magnetic data for archaeo-geophysical investigations in the Middle East: The case of Tell Barri (Syria). Archaeol. Prospect. 2019, 26, 379-395. [CrossRef]

50. Rizzo, E.; Chianese, D.; Lapenna, V. Magnetic, GPR and geoelectrical measurements for studying the archaeological site of 'Masseria Nigro' (Viggiano, southern Italy). Near Surf. Geophys. 2005, 3, 13-19. [CrossRef]

51. Asăndulesei, A. Inside a Cucuteni Settlement: Remote Sensing Techniques for Documenting an Unexplored Eneolithic Site from Northeastern Romania. Remote Sens. 2017, 9, 41. [CrossRef]

52. Paoletti, V.; Secomandi, M.; Piromallo, M.; Giordano, F.; Fedi, M.; Rapolla, A. Magnetic survey at the submerged archaeological site of Baia, Naples, Southern Italy. Archaeol. Prospect. 2005, 12, 51-59. [CrossRef] 
53. Bermejo Meléndez, J. Los sistemas defensivos del castellum de Tamuda. ¿torres de planta en abanico? Gladius 2014, 34, 111-124. [CrossRef]

54. Campos Carrasco, J.M.; Bermejo Meléndez, J.; Fernández Sutilo, L.; Toscano Pérez, C.; Salvador Delgado, A.; Gómez Rodríguez, A.; Verdugo Santos, J.; Ghottes, M. El castellum de Tamuda. Análisis Arqueoarquitectónico, Arqueología y turismo en el Círculo del Estrecho: Estrategias para la Puesta en Valor de los recursos patrimoniales del Norte de Marruecos, Actas del III Seminario Hispano-Marroqui (Algeciras, abril de 2011), Colección de Monografías del Museo Arqueológico de Tetuán (III); Servicio de Publicaciones de la Universidad de Cádiz: Cádiz, Spain, 2011; pp. 507-528.

55. Fassbinder, J.W.E. Geophysical Prospection of the Frontiers of the Roman Empire in Southern Germany, UNESCO World Heritage Site. Archaeol. Prospect. 2010, 17, 129-139. [CrossRef]

56. Gugl, C.; Neubauer, W.; Nau, E.; Jernej, R. New Evidence for a Roman Military Camp at Virunum (Noricum). Archaeol. Pol. 2015, 53, 289-292.

57. Pisz, M.; Tomas, A.; Hegyi, A. Non-destructive research in the surroundings of the Roman Fort Tibiscum (today Romania). Archaeol. Prospect. 2020, 27, 219-238. [CrossRef]

58. Walker, R.; Gaffney, C.; Gater, J.; Wood, E. Fluxgate Gradiometry and Square Array Resistance Survey at Drumlanrig, Dumfries and Galloway, Scotland. Archaeol. Prospect. 2005, 12, 131-136. [CrossRef]

59. Cerri, L. La prospezione magnetica: L'abitato antico. In Sidi Ali Ben Ahmed 1; Papi, E., Akerraz, A., Eds.; Quasar: Roma, Italy, 2008; pp. 31-50.

60. Papi, E. Diploma militare da Thamusida (Mauretania Tingitana). 103/4. Zeitschrift für Papyrologie und Epigraphik 2004, 146, $255-258$.

61. Papi, E.; e Akerraz, A. (Eds.) Sidi Ali Ben Ahmed-Thamusida 1; Quasar: Roma, Italy, 2008.

62. Akerraz, A.; Gliozzo, E.; Turbanti Memmi, I. (Eds.) Sidi Ali ben Ahmed-Thamusida 2. L'archeometria; Quasar: Roma, Italy, 2009.

63. Akerraz, A.; Camporeale, S.; Papi, E. Sidi Ali ben Ahmed-Thamusida 3. I Material; Quasar: Roma, Italy, 2014. 